\title{
Prevalence of active hepatitis $C$ virus infections among general public of Lahore, Pakistan
}

\author{
Muhammad Ikram Anwar', Moazur Rahman ${ }^{1}$, Mahmood UI Hassan² and Mazhar lqbal ${ }^{\text {1* }}$
}

\begin{abstract}
Background: To find out the prevalence of active hepatitis $\mathrm{C}$ virus (HCV) infections among general public in Lahore city, since data concerning the prevalence of active HCV in this city is currently unavailable.

Methods: Blood samples were collected randomly from individuals visiting different clinical laboratories in Lahore. Serum was separated and processed by nested PCR qualitative assay for the detection of HCV RNA. The samples were categorized into different age groups on the basis of pre-test questionnaires in order to record the age-wise differences regarding the prevalence of active HCV. Data were analyzed statistically using Chi-Square test.

Results: Out of the 4246 blood samples analyzed in this study, 210 were confirmed to be positive for active HCV infection. Gender-wise active HCV prevalence revealed no significant difference [OR $=1.10 \mathrm{Cl}=(0.83-1.46), p>0.05]$. However, among the age groups the highest prevalence was observed in the age groups 20-29 (7.7\%) and 30-39 years (6.4\%) with odds of prevalence of $14.8 \%(\mathrm{OR}=2.48, \mathrm{Cl}=(1.40-4.38), p<0.05)$ and $10.3 \%(\mathrm{OR}=2.03, \mathrm{Cl}=(1.10-3.71)$, respectively. In age groups above 40 years (40-49, 50-59 and $>59$ years), a decrease in levels of active HCV prevalence was observed.

Conclusions: Among tested samples, 4.9\% of the subjects were confirmed to harbour active HCV infections and the "middle aged" population in Lahore was found to be at a higher risk of the HCV ailments compared to both their younger and older peers.
\end{abstract}

Keywords: Active HCV prevalence, Lahore, Pakistan, Nested PCR

\section{Background}

Hepatitis $C$ is an infectious liver disease of humans and chimpanzees and is caused by the HCV [1]. The infection is often asymptomatic especially in its early stages but once established, it can progress to advanced liver diseases such as liver fibrosis and ultimately cirrhosis. These liver diseases can further lead to other complications such as liver failure and liver cancer [2]. In 2004, the World Health Organization (WHO) reported that annual deaths all over the world due to liver cancer and cirrhosis caused by HCV were about 308,000 and 785,000 , respectively [3]; and about 200 million people, the $3.3 \%$ of the world's population, are infected with $\mathrm{HCV}$ [4]. Moreover, around 3 to 4 million individuals are diagnosed as new cases every year [5].

\footnotetext{
* Correspondence: hamzamgondal@gmail.com

'Health Biotechnology Division, National Institute for Biotechnology and Genetic Engineering (NIBGE), Jhang Road, P. O. BOX 577, Faisalabad 38000, Pakistan

Full list of author information is available at the end of the article
}

In Pakistan an alarming rate of HCV outbreaks have been reported. The previous estimates indicate that around 10 million people are infected with $\mathrm{HCV}$ in Pakistan [6-8]. Prevalence of $\mathrm{HCV}$ has been noticed to be highly variable in different regions and even in different groups of the same community [9]. According to various studies, the presence of $\mathrm{HCV}$ infections among different categories (excluding chronic liver disease patients), was $5.31 \%$ in Islamabad [10], 0.4-31.9\% in various regions of Punjab province [6,7,11-13], 4-6\% in Sindh province $[6,7,13,14], 1.1-9 \%$ in Khyber Pakhtunkhwa province [6,7,13,15-17], $1.5 \%$ in Quetta region [12,13] and $25.7 \%$ in Gilgit Baltistan province $[18,19]$. While in Lahore, the second largest city of Pakistan with a population of more than 7 million [20], $\mathrm{HCV}$ prevalence was estimated from $0.58-17.78 \%[6,13,19,21-24]$.

Two major issues undermine the credibility of the published data: firstly, the number of samples included in most of the cohort studies were too small; secondly,

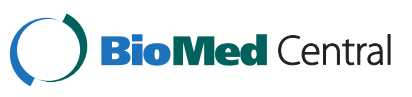


dissimilar methodologies adapted by various researchers made it highly inappropriate to conduct a formal metaanalysis to assess the accurate national prevalence [7]. Most of the studies conducted so far, have relied on the presence of anti-HCV antibodies in the blood samples using immunochromatographic tests (ICT), enzyme immunoassay (EIA), recombinant strip immunosorbent assay (RIBA) and enzyme linked immunosorbent assay (ELISA) techniques. All these techniques are fairly error prone and have been reported to generate around 50\% false positive results as compared to PCR confirmatory assay [15]. Approximately $60-85 \%$ of $\mathrm{HCV}$ patients can develop chronic hepatitis, while the remaining $15-40 \%$ can clear the HCV infection. A number of these individuals, however, can still be detected as $\mathrm{HCV}$ positive using non-PCR immunoassays such as ELISA, RIBA, EIA, ICT etc., due to the presence of anti-HCV antibodies in their blood [15]. Nevertheless, to date there is hardly any PCR based prevalence studies conducted in Pakistan with statistically representative number of samples. PCR has emerged as the most powerful diagnostic tool for the detection, quantification and genotyping of active HCV RNA in the blood.

In the present study, over 4000 blood samples were randomly collected from individuals visiting different clinical laboratories in Lahore, Pakistan. These samples were screened through confirmatory nested PCR qualitative assay to determine the percent prevalence of active $\mathrm{HCV}$ in various subjects. To the best of our knowledge, this is the first comprehensive report concerning the prevalence of active HCV in Pakistan's $2^{\text {nd }}$ largest city and its surroundings, with a statistically significant number of samples. The data was also correlated and categorized in terms of gender and age groups. This report will thus provide the $\mathrm{HCV}$ prevalence data for further metaanalysis that can help to devise strategies by the health policy makers for the control of hepatitis $\mathrm{C}$ disease.

\section{Results}

Out of 4246 blood samples, 1914 were collected from male and 2332 from female subjects. Moreover, all the individual samples were categorized into six age groups. The PCR results revealed that 210 (4.9\%) individuals had active HCV infection (Table 1). Gender-wise prevalence of active $\mathrm{HCV}$ infection was estimated to be $5.27 \%$ in male (101 positive out of 1914 samples) and $4.67 \%$ in female subjects (109 positive out of 2332 samples), respectively. Although the probability trends were slightly higher among males of all age groups than females, statistically there was no significant difference in gender with $\mathrm{OR}=$ $1.10 \mathrm{CI}=(0.83-1.46), p>0.05$, as elaborated in Table 1 .

Substantial differences were observed considering the age group criterion. Out of the 458 individuals tested in ages ranging from 9-19 years (both male and female), only $15(3.3 \%)$ were HCV positive. The highest numbers of positive individuals (69) with $7.7 \%$ prevalence were among the tested subjects (891) in the age group 2029 years (Table 1 and Figure 1). Statistically, the odd of prevalence of $\mathrm{HCV}$ in individuals in age group 2029 years was $14.8 \%$ higher than the individuals in age group 9-19 years $(\mathrm{OR}=2.48, \mathrm{CI}=(1.40-4.38), p<0.05)$, as illustrated in Table 1.

In the age group 30-39 years, HCV prevalence, though slightly less than that found for the 20-29 year group, was still significantly higher $(10.3 \%)$ as compared to age group 09-19 years $(\mathrm{OR}=2.03, \mathrm{CI}=(1.10-3.71)$. Subsequently, a decreasing trend of $\mathrm{HCV}$ prevalence was observed with increasing age of subjects above 40 years. The lowest prevalence $(3 \%)$ of active $\mathrm{HCV}$ was observed in the age group 59 years and above. Overall active $\mathrm{HCV}$ prevalence among all the tested samples was estimated to be $4.9 \%$ and the risk of $\mathrm{HCV}$ prevalence was significantly higher in the middle age groups (20-29 \& 30-39 years).

\section{Discussion}

In Pakistan, $\sim 6 \%$ population is suspected to be infected with $\mathrm{HCV}[6,7,25]$ and $\mathrm{HCV}$ prevalence data published so far is highly variable. In most of the studies conducted so far, either the number of samples reported are too small to draw any solid conclusion or the methodological differences have made it impossible to conduct a formal meta-analysis to determine accurate prevalence estimates [7]. Among all the published reports, 99\% of the data originated from erroneous non-PCR qualitative screening methodologies, mostly based on the detection of anti-HCV antibodies. Active $\mathrm{HCV}$ prevalence estimated during our research $(4.9 \%)$ is lower than that reported by Aslam et al. [24] (6.7\% based on 488 samples from the general population of Lahore). Similarly, the current estimate is much lower when compared with a nationwide data surveillance study conducted through an ELISA blood screen by Qureshi, et al. [12], who reported $6.8 \% \mathrm{HCV}$ prevalence in Lahore based general public. Our estimates were, however, much higher than those of another study in which 203 blood samples from staff and students of University of the Punjab, Lahore, were assayed through ELISA by Tanvir et al. in 2008 [26]. In yet another series of research conducted in pediatric population by Khan et al. [22], Parker et al. [23] and Hyder et al. [27] HCV prevalence was reported as $4.09 \%, 1.3 \%$ and $0.58 \%$, respectively, which is again lower as in comparison to our reported results (Table 2).

The only PCR-based HCV active prevalence study conducted in Lahore was reported by Zafar et al. [28] for a cohort of pregnant women. Out of 300 screened samples, $4 \%$ were found to be positive. Although this figure is relatively close to our figure $(4.9 \%)$ the number of samples 
Table 1 Prevalence of active hepatitis $C$ virus in general public of Lahore

\begin{tabular}{|c|c|c|c|c|c|c|c|c|}
\hline \multirow{2}{*}{$\begin{array}{l}\text { Age } \\
\text { groups }\end{array}$} & \multirow{2}{*}{$\begin{array}{c}\text { Total } \\
\text { samples }\end{array}$} & \multirow{2}{*}{$\begin{array}{l}\text { Male } \\
+/-\end{array}$} & \multirow{2}{*}{$\begin{array}{c}\text { Female } \\
+/-\end{array}$} & \multicolumn{2}{|c|}{ Probabilities $^{a}$} & \multirow[t]{2}{*}{$p$ value $^{c}$} & \multirow{2}{*}{$\begin{array}{l}\text { Odd ratio } \\
(95 \% \mathrm{Cl})\end{array}$} & \multirow{2}{*}{$\begin{array}{c}\text { Overall } \\
\text { prevalence } \%\end{array}$} \\
\hline & & & & Male & Female & & & \\
\hline $9-19$ & 458 & $9 / 211$ & $6 / 232$ & 0.0343 & 0.0313 & - & - & 3.3 \\
\hline \multirow[t]{2}{*}{$20-29$} & 891 & $31 / 399$ & $38 / 423$ & 0.0810 & 0.0741 & 0.002 & 2.48 & 7.7 \\
\hline & & & & & & & $(1.40-4.38)$ & \\
\hline \multirow[t]{2}{*}{$30-39$} & 625 & $24 / 258$ & $16 / 327$ & 0.0672 & 0.0614 & 0.023 & 2.03 & 6.7 \\
\hline & & & & & & & $(1.10-3.71)$ & \\
\hline \multirow[t]{2}{*}{$40-49$} & 654 & $14 / 296$ & $19 / 325$ & 0.0529 & 0.0483 & 0.155 & 1.57 & 5.1 \\
\hline & & & & & & & $(0.84-2.93)$ & \\
\hline \multirow[t]{2}{*}{$50-59$} & 730 & $11 / 298$ & $15 / 406$ & 0.0375 & 0.0342 & 0.779 & 1.10 & 3.6 \\
\hline & & & & & & & $(0.57-2.09)$ & \\
\hline \multirow[t]{2}{*}{$>59$} & 888 & $12 / 351$ & $15 / 510$ & 0.0321 & 0.0292 & 0.831 & 0.93 & 3.0 \\
\hline & & & & & & & $(0.49-1.77)$ & \\
\hline Total & 4246 & $101 / 1813$ & $109 / 2223$ & $0.0508^{b}$ & $0.0464^{b}$ & - & - & 4.9 \\
\hline
\end{tabular}

${ }^{a}$ Represents the estimated probabilities of HCV prevalence in male and female in different age groups calculated using the inverse transformation of logistic regression model. ${ }^{b}$ Average probability of six age groups of both genders. ${ }^{\mathrm{T}}$ The goodness of fit tests Pearson, deviance, and Hosmer-Lemeshow for the model have $p$ values ranging from 0.312 to 0.724 indicating the logistic regression model fit adequately $\mathrm{HCV}$ prevalence data. ${ }^{\mathrm{d}} \mathrm{Cl}$ (Confidence Interval) for male gender was $1.10(0.83-1.46)$ with $p$ value 0.497 .

Distribution of positive $\&$ negative in gender as well as age groups based criteria.

tested and the study subjects were less broad. Moreover, our active $\mathrm{HCV}$ prevalence estimate in general public of Lahore city is much lower than the values reported by Chaudhary et al. [29] and Akhtar et al. [21] among blood donors in Lahore, which revealed HCV prevalence as $6.06 \%$ and $17.78 \%$, respectively; indicating highly variable results (Table 2). Both studies were conducted using ELISA as a screening tool. HCV prevalence in IDUs [30] and haemophilia patients [31], reported as $88 \%$ and $56 \%$ respectively, are much higher in comparison with our results.

Gender-wise $\mathrm{HCV}$ prevalence revealed no significant difference $[\mathrm{OR}=1.10 \mathrm{CI}=(0.83-1.46), p>0.05]$ in male and female populations, as detailed in Table 1. Our study is in agreement with the previous country-wide as well as Lahore based surveys [12,20,32]. It is, however, in contrast with a recent study showing female to male ratio of 1:16.5 (Table 2) presumably due to the subjects were restricted only to blood donors and ELISA was used as a diagnostic tool [21].

Considering the age group criterion, significant differences were observed in the prevalence of $\mathrm{HCV}$ in both genders. The highest prevalence $7.7 \%$ and $6.4 \%$ were observed in age groups $20-29$ and $30-39$ years, respectively; with odds of prevalence of $14.8 \%(\mathrm{OR}=2.48, \mathrm{CI}=$ $(1.40-4.38), p<0.05)$ and $10.3 \%(\mathrm{OR}=2.03, \mathrm{CI}=(1.10-$

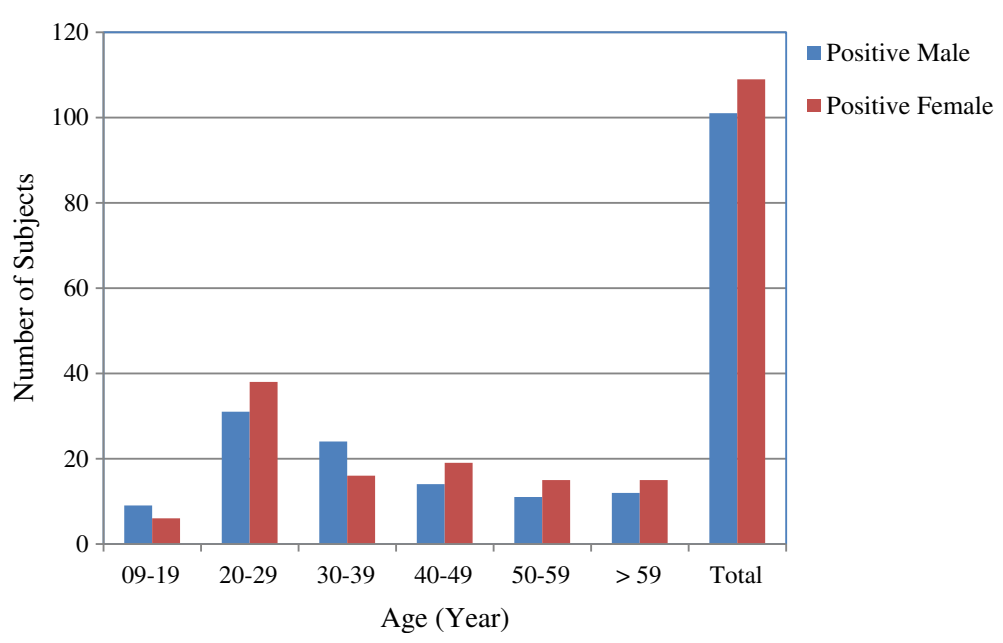

Figure 1 Prevalence of HCV positive samples in male/female population in different age groups. 
Table 2 Previous HCV prevalence data among different communities of Lahore

\begin{tabular}{|c|c|c|c|c|c|}
\hline Ref. \# & Population type & Author & Methods & Population size & HCV (\%) \\
\hline [24] & General population & Aslam et al. 2001 & $\mathrm{ICT}$ & 488 & 6.70 \\
\hline [26] & General population & Tanvir et al. 2008 & $\mathrm{ICT}$ & 203 & 1.48 \\
\hline$[12]$ & General population & Qureshi et al. 2010 & ELISA & $-^{a}$ & 6.80 \\
\hline [11] & General population & Bosan et al. 2010 & $I C T$, Lattix & $1501^{\mathbf{b}}$ & $2.1-13.5$ \\
\hline [22] & Pediatric population & Khan et al. 1996 & EIA, RIBA & 538 & 4.09 \\
\hline [23] & Pediatric population & Parker et al. 1999 & ELISA & 538 & 1.30 \\
\hline [27] & Pediatric population & Hyder et al. 2001 & ELISA & 171 & 0.58 \\
\hline [28] & Pregnant women & Zafar et al. 2001 & PCR & 300 & 4.00 \\
\hline [11] & & Bosan et al. 2010 & ELISA & $4108^{\mathbf{b}}$ & $6.8-7.3$ \\
\hline [29] & Blood donors & Chaudhary et al. 2005 & ELISA & 890 & 6.06 \\
\hline [11] & Blood donors & Bosan et al. 2010 & EIA, ELISA, ICT & $32326^{\mathbf{b}}$ & $4.1-6$ \\
\hline [21] & Blood donors & Akhtar et al. 2013 & ELISA & 245 & 17.78 \\
\hline [31] & Hemophilia & Malik et al. 2006 & ELISA & 100 & 56 \\
\hline [11] & Other high risk groups & Bosan et al. 2010 & ELISA & $412^{\mathbf{b}}$ & $19-56$ \\
\hline
\end{tabular}

${ }^{a}$ In this national survey, samples collected from Lahore region were not mentioned.

bData from a number of locally published reports, reviewed by Bosan et al. 2010 [11], have been combined.

3.71), respectively. Both of these values are higher compared to the age group 9-19 years. In age groups above 40 years (40-49, 50-59 and >59 years), a decreasing trend of active HCV prevalence was observed (Table 1). These results are in agreement with the previous studies particularly those conducted in Lahore city revealing the higher risk of $\mathrm{HCV}$ prevalence in middle aged groups (20-40 years) [20,24,33,34]. The high prevalence of $\mathrm{HCV}$ in middle aged groups can be correlated to more exposure of $\mathrm{HCV}$ infection and other risk factors such as non-blood transfusions, widespread reuse of syringes, and a range of other high-risk traditional practices.

\section{Conclusions}

Using the PCR based diagnostic assay for 4246 blood samples, the overall prevalence of active HCV was estimated as $4.9 \%$ in general public of Lahore. No significant differences in male and female genders were observed. However, HCV prevalence varied in different age groups. It was least prevalent in age groups 9-19 and above 59 years. However, middle aged populations, especially 20-29 and 30-39 year individuals were observed at higher risk of hepatitis $\mathrm{C}$ ailments with $7.7 \%$ and $6.4 \%$ active $\mathrm{HCV}$ prevalence, respectively. This report will provide the active $\mathrm{HCV}$ prevalence data for further meta-analysis, which can be helpful to health policy makers to devise strategies for the control of hepatitis $\mathrm{C}$ disease in Lahore in particular and in Pakistan in general. From the results of the present study, future PCR-based studies will result in lowering the previously reported estimates (i.e. 6\%) of prevalence of $\mathrm{HCV}$ in Pakistan.

\section{Methodology}

\section{Collection of blood samples}

In this study, 4246 blood samples were collected randomly from individuals visiting different clinical laboratories of Lahore between 2010 and 2012. As the study was designed to represent the general public HCV prevalence, the samples were collected randomly from individuals who visited laboratories for any purpose such as some clinical test, sample submission, report collection or blood screen etc. Samples were collected from both genders having ages ranging from 9 to $>59$ years. Informed consent was taken from every individual being tested and approval was obtained from institutional ethical review committee. History of individuals was recorded in the form of questionnaires. Serum from each of these blood samples were separated by centrifugation at $4000 \mathrm{rpm}$ for $5 \mathrm{~min}$. Each sample was properly labeled and stored at $-20^{\circ} \mathrm{C}$ until (on every coming Monday) it was shifted to National Institute for Biotechnology \& Genetic Engineering (NIBGE) Faisalabad for PCR diagnostic assay. Besides the gender groups, samples were also categorized into six age groups to determine the prevalence in each age group.

\section{Viral RNA extraction and CDNA formation}

RNA was extracted from these samples using the Qiamp Viral RNA extraction kit (Qiagen, USA) according to manufacturer's instruction. Serum sample $(140 \mu \mathrm{l})$ was used to extract RNA that was eluted in $60 \mu$ l elution buffer supplied with kit. RNA was used in making cDNA immediately after extracting RNA or stored at $-80^{\circ} \mathrm{C}$ for further use. cDNA was prepared in a total reaction 
volume of $20 \mu \mathrm{l}$ containing $10 \mu \mathrm{l}$ of RNA extracted from each sample. For cDNA formation, First Strand cDNA synthesis kit (Thermo scientific, USA) was used. Briefly, the extracted RNA was mixed with 20 picomol of gene specific primer (5' GTGCACGGTCTACGAGACCT 3') and 200 units Moloney Murine Leukemia Virus (M-MuLV) reverse transcriptase and incubated at $42^{\circ} \mathrm{C}$ for 60 min with light shaking. After incubation, cDNA was properly labeled and stored at $-20^{\circ} \mathrm{C}$ for PCR amplification.

\section{Polymerase chain reaction amplification of CDNA}

Amplification of cDNA was performed according to Petrelli [35]. A reaction mixture of $50 \mu \mathrm{l}$ containing $5 \mu \mathrm{l}$ of cDNA, $0.2 \mathrm{mM}$ dNTPs, $2 \mathrm{mM} \mathrm{MgCl}_{2}, 0.5 \mu \mathrm{M}$ of forward primer, $0.5 \mu \mathrm{M}$ of reverse primer, $2.5 \mathrm{U}$ of Taq DNA Polymerase and $1 \mathrm{X}$ Taq polymerase Buffer (75 mM Tris- $\mathrm{HCl} \mathrm{pH} 8.8,20 \mathrm{mM}\left(\mathrm{NH}_{4}\right)_{2} \mathrm{SO}_{4}, 0.01 \%$ Tween) [Fermentas] was prepared and amplification was carried out in a thermal cycler (Biorad). For amplification of first round of PCR, conditions used were $94^{\circ} \mathrm{C}$ for 2 min followed by 30 cycles with the temperature profile $94^{\circ} \mathrm{C}$ for $30 \mathrm{sec}, 55^{\circ} \mathrm{C}$ for $30 \mathrm{sec}$ and $72^{\circ} \mathrm{C}$ for $30 \mathrm{sec}$ and final extension was performed for $2 \mathrm{~min}$ at $72^{\circ} \mathrm{C}$. The PCR products were used as template for nested PCR amplification. The temperature conditions were the same as in the first round of PCR except the primers used, which were complementary to the PCR product of first round PCR [36].

\section{Analysis of PCR product}

The amplified PCR products of nested PCR were run on $1 \%$ agarose gel prepared in $1 \mathrm{X}$ TBE (Trizma base, boric acid) buffer. Ethidium bromide dye $(3 \mu \mathrm{L}$, $1 \% \mathrm{w} / \mathrm{v})$ was also added in order to make the bands visible under UV light. The samples were loaded into the well by mixing with bromophenol blue and gel was run under constant voltage of 80 until the dye reached the other end of the gel. The bands were visualized under UV light. The sensitivity of the PCR based qualitative assay was noticed around $200 \mathrm{IU}$ per $\mathrm{ml}$ of the sample.

\section{Statistical analysis}

All of the PCR based HCV qualitative data were statistically analyzed using Minitab version 16.2 for Windows. Binary Logistic regression was performed in order to examine the prevalence of $\mathrm{HCV}$ associated with sex and age. Statistical tests of the regression estimates or odds ratios (OR) were based on Wald statistics. The Hosmer-Lemeshow statistics has suggested that the logistic regression model fit the data adequately and 95\% confidence intervals for odd ratios were calculated. A $p$-value $<0.05$ was defined as statistically significant.

\section{Abbreviations}

HCV: Hepatitis C virus; IDUs: Injection drug users;

ICT: Immunochromatographic; EIA: Enzyme immunoassay; RIBA: Recombinant strip immunosorbent assay; ELISA: Enzyme linked immunosorbent assay; RT-PCR: Reverse transcriptase polymerase chain reaction; CDNA: Complimentary DNA; WHO: World Health Organization; OR: Odd ratio; Cl: Confidence interval,

\section{Competing interests}

The authors declare that they have no competing interests.

\section{Authors' contributions}

MIA carried out mainly this prevalence studies. He collected the samples, got the consent of subjects and performed PCR based qualitative assays. MR shared the cost of research, helped in design of study and contributed in manuscript preparation. MUH conducted the statistical analysis and helped in getting the samples. MI mainly supervised this study and prepared the manuscript. All authors read and approved the final manuscript.

\section{Authors' information}

${ }^{1}$ MIA PhD student, MR Senior Scientist \& MI Principal Scientist/Group Leader at Drug Discovery and Structural Biology, Health Biotechnology Division, National Institute for Biotechnology and Genetic Engineering (NIBGE), Faisalabad-38000, Pakistan. ${ }^{2} \mathrm{MUH}$ is currently MS student at Department of Statistics, Stockholm University, SE - 106 91, Stockholm, Sweden.

\section{Acknowledgements}

We want to extend our gratitude to the Higher Education Commission (HEC), Pakistan for providing financial support for the current study since the first author (MIA) is a recipient of Ph. D. indigenous scholarship batch-III, offered by HEC, Pakistan. We are also thankful to Dr Abdul Haque, Dr Waqar Rauf and Dr Paul Evans for the proof reading of this manuscript.

\section{Author details}

${ }^{1}$ Health Biotechnology Division, National Institute for Biotechnology and Genetic Engineering (NIBGE), Jhang Road, P. O. BOX 577, Faisalabad 38000, Pakistan. ${ }^{2}$ Department of Statistics, Stockholm University, Stockholm, SE 106 91, Sweden.

Received: 17 July 2013 Accepted: 2 December 2013

Published: 5 December 2013

\section{References}

1. Chen SL, Morgan TR: The natural history of hepatitis C virus (HCV) infection. Int J Med Sci 2006, 3:47-52.

2. Villano SA, Vlahov D, Nelson KE, Cohn S, Thomas DL: Persistence of viremia and the importance of long-term follow-up after acute hepatitis $C$ infection. Hepatology 1999, 29:908-914.

3. World Health Organization: Department of Measurement and Health Information. December 2004. http://www.who.int/healthinfo/statistics/ bodgbddeathdalyestimates.xls.

4. Diseases; Hepatitis C. [http://www.who.int/csr/disease/hepatitis/ whocdscsrlyo2003/en/index3.html], [Accessed in 2011].

5. Ray Kim W: Global epidemiology and burden of hepatitis C. Microbes Infect 2002, 4:1219-1225.

6. Waheed Y, Shafi T, Safi SZ, Qadri I: Hepatitis C virus in Pakistan: a systematic review of prevalence, genotypes and risk factors. World J Gastroenterol 2009, 15:5647-5653.

7. Ali SA, Donahue RM, Qureshi H, Vermund $\mathrm{SH}$ : Hepatitis B and hepatitis C in Pakistan: prevalence and risk factors. Int J Infect Dis 2009, 13:9-19.

8. Raja NS, Janjua KA: Epidemiology of hepatitis $C$ virus infection in Pakistan. J Microbiol Immunol Infect 2008, 41:4-8.

9. Muzaffar F, Hussain I, Haroon TS: Hepatitis C: the dermatologic profile. J Pak Assoc Dermatol 2008, 18:171-181.

10. Masood R, Sardar MA, Mallhi AA: Seroprevalence of hepatitis B and C among the healthy blood donors at Fauji Foundation Hospital, Rawalpindi. Pak J Med Sci 2007, 23:64-67.

11. Bosan A, Qureshi H, Bile KM, Ahmad I, Hafiz R: A review of hepatitis viral infections in Pakistan. J Pak Med Assoc 2010, 60:1045-1058.

12. Qureshi H, Bile KM, Jooma R, Alam SE, Afridi HU: Prevalence of hepatitis B and $C$ viral infections in Pakistan: findings of a national survey appealing 
for effective prevention and control measures. East Mediterr Health J 2010, 16(Suppl):S15-S23.

13. Kazmi KSA, Dil AS, Zuberi SJ: Prevalence of HCV in blood donors. Pak $J$ Med Res 1997, 36:61-62.

14. Khan MSA, Khalid M, Ayub N, Javed M: Seroprevalence and risk factors of hepatitis C virus (HCV) in Mardan, NWFP: a hospital based study. Rawal Med J 2004, 29:57-60.

15. Ali A, Ahmad H, Ali I, Khan S, Zaidi G, Idrees M: Prevalence of active hepatitis c virus infection in district mansehra pakistan. Virol I 2010, 7:334.

16. Muhammad N, Jan MA: Frequency of hepatitis " $\mathrm{C}$ " in Buner, NWFP. J Coll Physicians Surg 2005, 15:11-14.

17. Tariq WU, Hussain AB, Karamat KA, Ghani E, Hussain T, Hussain S: Demographic aspects of hepatitis $C$ in northern Pakistan. J Pak Med Assoc 1999, 49:198-201.

18. Akbar H, Idrees M, Manzoor S, Rehman IU, Butt S, Yousaf M, Rafique S, Awan Z, Khubaib B, Akram M: Hepatitis C virus infection: a review of the current and future aspects and concerns in Pakistan. J Gen Mol Virol 2009, 1:12-18.

19. Batool SA, Chaudhry N, Majeed K: Economic potential of recycling business in Lahore, Pakistan. Waste Manag 2008, 28:294-298.

20. Ahmad W, ljaz B, Javed FT, Jahan S, Shahid I, Khan FM, Hassan S: HCV genotype distribution and possible transmission risks in Lahore, Pakistan. World I Gastroenterol 2010, 16:4321-4328.

21. Akhtar AM, Khan MA, ljaz T, lqbal Z, Rana MY, Maqbool A, Rehman A: Seroprevalence and Determinants of Hepatitis-C Virus Infection in Blood Donors of Lahore, Pakistan. Pak J Zool 2013, 45:1-7.

22. Khan $\mathrm{H}$ : A study of seroprevalence of hepatitis $B$ and $C$ in mothers and children in Lahore. Pak Pediatr J 1996, 20:163-166.

23. Parker S, Khan H, Cubitt W: Detection of antibodies to hepatitis C virus in dried blood spot samples from mothers and their offspring in Lahore, Pakistan. J Clin Microbiol 1999, 37:2061-2063.

24. Aslam M, Aslam J: Seroprevalence of the antibody to hepatitis C in select groups in the Punjab region of Pakistan. J Clin Gastroenterol 2001, 33:407-411.

25. Idrees $\mathrm{M}$, Riazuddin S: Frequency distribution of hepatitis $\mathrm{C}$ virus genotypes in different geographical regions of Pakistan and their possible routes of transmission. BMC Infect Dis 2008, 8:69.

26. Tanveer A, Batool K, Qureshi AW: Prevalence of hepatitis B and c in university of the Punjab, Quaid-e-azam campus, Lahore. J Agric Biol SC 2008, 3:30-32

27. Hyder S, Hussain W, Aslam M, Maqbool S: Seroprevalence of anti-HCV in asymptomatic children. Pak J Pathol 2001, 12:89-93.

28. Zafar MMA, Husain I, Shah A: Prevalence of hepatitis $\mathrm{C}$ among pregnant women. J Surg Pak 2001, 6:32-33.

29. Chaudry NTJW, Ihsan I, Nasreen S: Hepatitis C. Prof Med J 2005, 12:364-367.

30. Zafar T, Ahmed MA, Strathdee SA: High HCV seroprevalence and HIV drug use risk behaviors among injection drug users in Pakistan. Harm Reduc J 2006, 3:26

31. Malik N, Hussain Z, Khan M: Markers of viral hepatitis in hemophiliacs. Biomedica 2006, 22:48-50.

32. Afridi SQ, Zahid MN, Shabbir MZ, Hussain Z, Mukhtar N, Tipu MY, Akhtar F, Yaqub T: Prevalence of HCV genotypes in district Mardan. Virol J 2013, 10:90.

33. Inamullah, Idrees M, Ahmed H, Sajid u g, Ali M, Ali L, Ahmed A: Hepatitis C virus genotypes circulating in district Swat of Khyber Pakhtoonkhaw, Pakistan. Virol J 2011, 8:16

34. Masood Z, Jawaid M, Khan RA, Rehman S: Screening for hepatitis B \& C a routine pre-operative investigation. Pak J Med Sci 2005, 21:455-459.

35. Petrelli E, Manzin A, Paolucci S, Cioppi A, Brugia M, Muretto P, Clementi M: Chronic liver disease and active hepatitis $C$ virus infection in patients with antibodies to this virus. J Clin Pathol 1994, 47:148-151.

36. Ahmad N, Asgher M, Shafique M, Qureshi JA: An evidence of high prevalence of Hepatitis C virus in Faisalabad, Pakistan. Saudi Med J 2007, 28:390-395.

doi:10.1186/1743-422X-10-351

Cite this article as: Anwar et al: Prevalence of active hepatitis $C$ virus infections among general public of Lahore, Pakistan. Virology Journal 2013 10:351.

\section{Submit your next manuscript to BioMed Central and take full advantage of:}

- Convenient online submission

- Thorough peer review

- No space constraints or color figure charges

- Immediate publication on acceptance

- Inclusion in PubMed, CAS, Scopus and Google Scholar

- Research which is freely available for redistribution

Submit your manuscript at www.biomedcentral.com/submit

C Biomed Central 